Aleksandra Bartosiewicz

(Uniwersytet Łódzki

Wydział Ekonomiczno-Socjologiczny)

\title{
POROZUMIENIA INTEGRACYJNE W KONTENEROWEJ \\ ŻEGLUDZE MORSKIEJ. GENEZA, ROZWÓJ I STAN \\ OBECNY W KONTEKŚCIE OBOWIĄZUJĄCYCH PRZEPISÓW UNII EUROPEJSKIEJ
}

\section{Wstęp}

W

spólną politykę wobec transportu morskiego zaczęto kształtować w Europie dopiero w połowie lat 70. XX w. To opóźnienie wynikało głównie z zapisów w Traktacie Rzymskim o powołaniu Europejskiej Wspólnoty Gospodarczej, zgodnie z którymi ewentualne postanowienia o wspólnej polityce $\mathrm{w}$ transporcie morskim odłożono na bliżej nieokreśloną przyszłość. Kiedy w 1962 r. Rada uchwaliła rozporządzenie nr 17/62 wprowadzające w życie traktatowe reguły konkurencji, jeszcze w tym samym roku wydane zostało przez nią rozporządzenie $\mathrm{nr}$ 141/62 wyłączające spod przepisów konkurencyjnych całość transportu. Jak się okazało, w odniesieniu do żeglugi morskiej przepisy te obowiązywały aż do końca 1986 r. W dalszej części artykułu przedstawione zostaną podstawowe rodzaje porozumień integracyjnych pomiędzy armatorami działającymi $\mathrm{w}$ żegludze kontenerowej oraz zmieniający się z biegiem lat stosunek Unii Europejskiej do kwestii swobody świadczenia usług w transporcie morskim.

\section{Geneza i rozwój morskich przewozów kontenerowych}

Żegluga morska jest jedną z najstarszych form przewozu pasażerów i ładunków. Transport morski od zawsze stanowił ważny element rozwoju gospodarczego poszczególnych krajów. Również i dziś, głównie ze względu na duży zasięg i ogromne możliwości przewozowe, jest on jedną z największych i najlepiej rozwiniętych gałęzi transportu. Potwierdzają to dane statystyczne, przez morskie szlaki handlowe przechodzi ok. $2 / 3$ wszystkich towarów na świecie ${ }^{1}$. Jednym z elementów wpływających na szybką globalizację wymiany towarowej był przede wszystkim szybki rozwój morskich przewozów kontenerowych.

${ }^{1}$ J. Kupiński, J. Fabisiak, J. Michalak, Morskie przewozy kontenerowe w Polsce i na świecie - geneza i rozwój, „Logistyka” 2011, nr 5, s. 780. 
Początki konteneryzowania ładunków przypadły na lata, kiedy porty stały się wąskim gardłem przewozów. Największe straty z tego tytułu ponosili przede wszystkim przewoźnicy morscy. Koniec lat 60 . XX w. to początek dynamicznego rozwoju konteneryzacji $\mathrm{w}$ międzynarodowym transporcie morskim. $\mathrm{O}$ ile w 1966 r. istniało pięć linii żeglugowych świadczących przewozy kontenerowe na szlaku północno-atlantydzkim między USA a Europą Zachodnią, to w 1967 r. w Stanach Zjednoczonych funkcjonowało ich już 38, o zasięgu powiększonym o Bliski i Daleki Wschód, Afrykę oraz Amerykę Łacińską. W roku 1968 podobne połączenia powstały na Pacyfiku. Następnie w 1969 r. utworzono szlaki żeglugowe łączące Amerykę Północną i Europę z Australią. W 1972 r. drugie z tych połączeń rozszerzono o Japonię i Azję, a w dwa, trzy lata później o Afrykę i rejon Morza Karaibskiego. W kolejnych latach do głównych linii dołączono uzupełniające szlaki z mniej uprzemysłowionych rejonów świata².

Wraz z rozwojem linii transportowych trwała rozbudowa sieci portów i terminali kontenerowych. W latach 80. ubiegłego stulecia głównymi ośrodkami transportu kontenerowego były węzły morskie Ameryki Północnej, Europy Zachodniej i Azji. Początek XXI w. to czas wyraźnej dominacji portów azjatyckich, zwłaszcza chińskich. Biorąc pod uwagę wielkość przeładunków w TEU³ , w 2014 r. w pierwszej dwudziestce portów kontenerowych znalazły się zaledwie trzy europejskie (Rotterdam, Hamburg, Antwerpia) i jeden amerykański (Los Angeles) ${ }^{4}$.

Pierwsza dekada XXI w. jest okresem, w którym wykształcił się nowy charakter przewozów kontenerowych. Obecnie linie oceaniczne łączą kluczowe porty bazowe, zaś lokalne porty drugorzędne zapewniają serwis dowozowo-odwozowy pomiędzy tymi portami, do których nie zawijają kontenerowce oceaniczne. W opisanym systemie wyróżnia się zatem dwa typy przewozów: równoleżnikowe przewozy oceaniczne łączące główne rynki (Azja - Europa - Ameryka Północna) oraz południkowy serwis dowozowy, który ma za zadanie rozwozić kontenery pomiędzy portami bazowymi i rozmieszczonymi wzdłuż wybrzeży poszczególnych kontynentów morskimi węzłami lokalnymi ${ }^{5}$.

Jak wynika z powyższego, wprowadzenie do transportu konteneryzacji zapoczątkowało jakościową zmianę, która umożliwiła procesy globalizacji produkcji oraz wpłynęła na środki transportu, porty, jak i organizację całych łańcuchów transportowych. W momencie pojawienia się kontenerów również przedsiębiorstwa armatorskie stanęły w obliczu nowych wyzwań technologicznych, finansowych

2 Z. Krasucki, J. Neider, Konteneryzacja w transporcie międzynarodowym, Warszawa 1986, s. 33-34; A. Salomon, Spedycja w handlu morskim: procedury i dokumenty, Gdańsk 2003, s. 191-192.

${ }^{3}$ TEU (ang. Twenty-foot Equivalent Unit) to jednostka pojemności równoważna objętości kontenera o długości dwudziestu stóp.

${ }^{4}$ Top 50 world container ports, http://www.worldshipping.org/about-the-industry/global-trade/ top-50-world-container-ports [dostęp: 23.02.2015].

${ }^{5}$ I. Urbanyi-Popiołek, Obstuga ładunków skonteneryzowanych. Wybrane zagadnienia, Gdynia 2010, s. 25. 
i organizacyjnych. Przejawem tendencji do ograniczania ryzyka inwestycyjnego i handlowego oraz zwiększania mobilności armatorów stały się różnego rodzaju porozumienia integracyjne ${ }^{6}$.

\section{Porozumienia integracyjne w kontenerowej żegludze morskiej}

Ze względu na organizację przewozu wyróżnić można żeglugę regularną (liniową) i nieregularną. Głównym przedmiotem przewozu tej drugiej są ładunki masowe. Rynek żeglugi nieregularnej dzieli się na otwarty (tramping) oraz specjalny (żegluga koncernowa). Elementem regulującym funkcjonowanie otwartych rynków żeglugi nieregularnej są giełdy frachtowe, na których działają maklerzy frachtujący, czyli pośrednicy pomiędzy przewoźnikami dysponującymi odpowiednim statkiem, a czarterującymi chcącymi przewieść określony ładunek. Z kolei przewozy w ramach żeglugi koncernowej odbywają się na warunkach wieloletnich czarterów lub kontraktów przewozowych. Tutaj relacje pomiędzy przewoźnikami i usługobiorcami są niejawne?

Żegluga regularna bazuje na eksploatacji linii żeglugowej, na którą składają się co najmniej dwa statki utrzymujące regularne połączenia pomiędzy wyznaczonymi portami morskimi. W tym przypadku przewoźnicy zawierają z załadowcami szereg umów bukingowych w oparciu o taryfowy system kwotowania stawek frachtowych ${ }^{8}$. Co ciekawe, do dynamicznie rozwijającej się części rynku żeglugi regularnej należą międzynarodowe przewozy ładunków skonteneryzowanych ${ }^{9}$.

Konteneryzacja przyczyniła się do spotęgowania zjawiska koncentracji kapitału w żegludze i centralizowania organizacji przewozów. Aby uzyskać przewagę konkurencyjną na rynku, armatorzy zaczęli stopniowo poszukiwać nowych form współpracy, tworząc żeglugowe konsorcja kontenerowe, alianse globalne i wymieniając pomiędzy sobą sloty ${ }^{10}$.

Na przełomie lat 70. i 80. XX w. pojawiać zaczęły się żeglugowe konsorcja kontenerowe ${ }^{11}$, będące związkiem kilku armatorów, którzy w celu eksploatowania danego szlaku powoływali do życia wyodrębnione organizacyjnie wspólne przedsięwzięcie. Przy tej formie współpracy armatorzy tracą co prawda całkowicie lub częściowo pozycję niezależnych przewoźników, ale odnosi się to tylko do obsługi

\footnotetext{
${ }^{6}$ M. Brzozowski, Morskie przewozy kontenerowe jako generator zmian, „Logistyka” 2011, nr 4, s. 120.

${ }^{7}$ T. Nowosielski, Kierunki rozwoju rynków żeglugowych, „Contemporary Economy”, Vol. 3, Issue 2/2012, s. 23-24.

${ }^{8}$ Fracht, wynagrodzenie przewoźnika za transport ładunku, ustalany jest wtedy zgodnie z obowiązującą taryfą.

${ }^{9}$ T. Nowosielski, Kierunki rozwoju..., s. 25.

${ }^{10}$ Całą przestrzeń ładunkową statku dzieli się na sloty, czyli stanowiska na umieszczenie kontenera. Por. J. Neider, Przewozy intermodalne w transporcie międzynarodowym, Gdańsk 1992, s. 24.

${ }^{11}$ Jednym z najstarszych konsorcjów kontenerowych jest, działające od 1967 r. na szlaku Ameryka Północna-Europa, Atlantic Container Line.
} 
wybranego szlaku. Takie porozumienie integracyjne umożliwia prowadzenie jednolitej polityki inwestycyjnej i żeglugowej oraz wspólną akwizycję i marketing, organizację i kontrolę przewozów czy też eksploatację statków i kontenerów ${ }^{12}$.

Wśród konsorcjów można wyróżnić porozumienia kartelowe, syndykaty kontenerowe, grupy kontenerowe oraz tzw. joint ventures. Kartele są to porozumienia między przedsiębiorstwami działającymi w tej samej branży gospodarki, których celem jest horyzontalne ograniczanie lub całkowite wyeliminowanie wzajemnej konkurencji pomiędzy nimi mające na celu zwiększenie zysków. W żegludze morskiej uczestnicy porozumienia kartelowego najczęściej ustalają wspólne plany rejsów, udziały ładunków do przewozu w kontenerach dla każdego z partnerów oraz jednolite taryfy frachtowe. Co istotne, pomimo wspólnej nazwy firmy nie tracą osobowości prawnej, a armatorzy odpowiadają za techniczną eksploatację swoich statków ${ }^{13}$.

Syndykat kontenerowy to wyższy stopień zarządzania wspólnym przedsięwzięciem armatorskim niż porozumienie kartelowe. Wobec tego, poza elementami współpracy charakterystycznymi dla karteli, członkowie syndykatu prowadzą dodatkowo wspólny marketing i operacje lądowe oraz ściśle koordynują inwestycje tonażowe od strony finansowej. Rozliczają oni swoje przychody na zasadach poolu finansowego ${ }^{14}$, a uprawnienia transportowe armatorów ustalają proporcjonalnie do potencjału przewozowego każdego z nich lub na podstawie wyników działalności z poprzednich okresów ${ }^{15}$.

Jeszcze wyższy stopień integracji pomiędzy armatorami zapewnia grupa kontenerowa, która ma charakter spółki akcyjnej i kieruje praktycznie wszystkimi operacjami swoich udziałowców. Zarząd grupy odpowiedzialny jest nie tylko za wspólną działalność charakterystyczną dla syndykatów, ale zapewnia też centralną dyspozycję tonażem oraz parkiem kontenerowym, operuje ujednoliconą dokumentacją przewozowo-finansową czy też rozlicza koszty i wpływy. Co więcej, zajmuje się on również organizacją transportu kontenerów na lądzie współpracując z przewoźnikami samochodowymi i kolejowymi. O ile w tego typu porozumieniu statki są własnością poszczególnych armatorów, to decyzje inwestycyjne co do ich typu i wielkości podejmowane są przez całą grupę ${ }^{16}$.

${ }^{12}$ Deloitte, Porty morskie jako ogniwa międzynarodowych multimodalnych ciagów transportowych $w$ obrocie ladowym i lądowo-morskim ze szczególnym uwzględnieniem zagadnień konkurencji międzygałęziowej oraz substytucyjności poszczególnych rodzajów transportu, projekt 2004/016 -829.02.03 Ochrony Konkurencji, 2007, ftp://ftpf.uokik.gov.pl/analizy/rezultat5_v2.pdf [dostęp: 14.05.2012], s. 17.

${ }^{13}$ R. Molski, Kartele eksportowe w świetle prawa ochrony konkurencji, ,Ruch Prawniczy, Ekonomiczny i Socjologiczny” 2003, z. 3, s. 17.

${ }^{14}$ Jest to rodzaj umowy o podziale wpływów frachtowych.

${ }^{15}$ J. Neider, D. Marciniak-Neider, Transport intermodalny, Warszawa 1997, s. 87.

${ }^{16}$ Tamże, s. 88. 
Wreszcie najwyższym stopniem kooperacji $\mathrm{w}$ żegludze morskiej są porozumienia typu joint venture. Ta forma współpracy zakłada współdziałanie we wszystkich dziedzinach działalności armatorskiej. Zarówno statki, jak i terminale są własnością joint venture, a nie poszczególnych przewoźników. Join venture to najczęściej odrębne podmioty stworzone wspólnie przez więcej niż jedno przedsiębiorstwo w celu realizacji określonego zadania lub prowadzenia konkretnej działalności. W żegludze morskiej spółki tego typu nie ograniczają swoich działań do jednego szlaku ${ }^{17}$.

Kiedy w drugiej połowie lat 80 . XX w. wiele konsorcjów rozpadło się, a niektóre ograniczyły stopień integracji pomiędzy swoimi uczestnikami, na popularności zaczęły ponownie zyskiwać konferencje żeglugowe, tj. porozumienia armatorów z różnych krajów obsługujących ten sam obszar, porty i linie żeglugowe. Członkowie konferencji ustalają wysokość opłat frachtowych, rozkłady rejsowe, tonaż przewozowy oraz inne warunki obsługi żeglugowej na danym obszarze. Ich głównym celem jest ograniczanie konkurencji cenowej ${ }^{18}$. W tym czasie powstawały także elastyczniejsze formy współpracy, tzw. porozumienia stabilizacyjne, które poza tym, że określają wspólne stawki taryfowe, to bazują też na wymianie przestrzeni ładunkowej między przewoźnikami oraz wyznaczaniu pojemności statków oferowanych przez sygnatariuszy umowy.

Ponadto w drugiej połowie lat 80 . XX w. indywidualni armatorzy uruchomili serwisy okołoziemskie. Ponieważ samodzielne zaistnienie przewoźnika morskiego na światowym rynku żeglugowym stawało się coraz trudniejsze, w połowie lat 90. ubiegłego stulecia nastąpiła też fala fuzji, połączeń i różnego rodzaju aliansów. Alianse globalne nie wiążą co prawda tak blisko armatorów jak konsorcja żeglugowe, ale za to dotyczą obsługi już nie tylko jednego serwisu żeglugowego, ale wielu. Zapewniają one ponadto wspólną eksploatację statków, na których dokonuje się wzajemnego frachtowania stanowisk kontenerowych. Przewidują także tworzenie poolów kontenerowych ${ }^{19}$, wspólne wykorzystanie terminali portowych oraz jednolity rozkład rejsów ${ }^{20}$.

Dzięki prowadzeniu działań konsolidacyjnych operatorzy kontenerowi mają większe szanse przetrwania na rynkach frachtowych. W wyniku opisanych powyżej procesów integracyjnych, od lat 90 . XX w. decydujący wpływ na liniową żeglugę kontenerową zdobyło nieliczne grono megaarmatorów oraz konsorcjów żeglugowych. Obecnie coraz większy potencjał przewozowy skupiony jest w rękach zaledwie kilkunastu przedsiębiorstw posiadających przeszło $75 \%$ udziału w światowej

${ }^{17}$ G.J.B. Probst, Ch. C. Rülling, Joint Ventures und Joint Venture-Management, [w:] H. Schaumberg, Internationale Joint Venture, Stuttgart 1999, s. 5.

${ }_{18}$ Por. I. Grajewski, J. Wójcicki, Mały leksykon morski, Warszawa 1981.

${ }^{19}$ Rodzaj porozumienia, w którym ma miejsce wspólna eksploatacja parku kontenerowego przez jedno centrum logistyczne.

${ }^{20}$ Deloitte, $d z$. cyt., s. 17. 
flocie kontenerowej ${ }^{21}$. Na rynku żeglugi kontenerowej występuje ok. stu liczących się operatorów. Największą zdolnością przewozową dysponuje jednak pierwsza dziesiątka przedsiębiorstw ze swoim wieloletnim liderem, APM-Maersk ${ }^{22}$ (zob. tabela 1). Warto jednocześnie zauważyć, że poza dużymi operatorami, utrzymującymi połączenia globalne, istnieje też rynek niszowy drobnych przewoźników liniowych świadczących usługi dowozowo-odwozowe na szlakach lokalnych.

Tabela 1

Lista dziesięciu największych operatorów kontenerowych na świecie (stan na 2015 r.)

\begin{tabular}{|c|l|c|c|}
\hline \multirow{2}{*}{ Pozycja } & \multirow{2}{*}{ Nazwa } & \multicolumn{2}{|c|}{ Flota kontenerowa } \\
\cline { 3 - 4 } & & 2971591 & Pojemność (TEU) \\
\hline 1 & APM-Maersk & 2527867 & 610 \\
\hline 2 & Mediterranean Shg Co & 1692906 & 497 \\
\hline 3 & CMA CGM Group & 966988 & 182 \\
\hline 4 & Hapag-Lloyd & 963599 & 202 \\
\hline 5 & Evergreen Line & 816318 & 161 \\
\hline 6 & COSCO Container L. & 703331 & 140 \\
\hline 7 & CSCL & 630215 & 101 \\
\hline 8 & Hanjin Shipping & 595872 & 111 \\
\hline 9 & MOL & 546100 & 89 \\
\hline 10 & APL & & \\
\hline
\end{tabular}

Źródło: http://www.alphaliner.com/top100

Biorąc pod uwagę podział geograficzny, można stwierdzić, że na rynku dominują operatorzy europejscy (cztery pierwsze miejsca w tab. 1). Jednak już wkrótce ich pozycji zagrozić mogą przewoźnicy reprezentujący Daleki Wschód. Na chwilę obecną rynek dalekowschodni kontrolowany jest przez armatorów z Chin, Tajwanu, Korei Południowej i Japonii. Największymi operatorami kontenerowymi w tej grupie są tajwański Evergreen oraz chińskie COSCO.

${ }^{21}$ T. Nowosielski, Koncentracja $w$ żegludze liniowej, „Namiary na Morze i Handel” 2006, nr 22, s. 15.

${ }^{22}$ Tenże, Kierunki rozwoju..., s. 31. 
Z kolei na początku XXI w. na popularności zyskała forma współpracy polegająca na frachtowaniu stanowisk kontenerowych (ang. slot exchange), w której armatorzy dzielą przestrzeń ładunkową swoich statków na sloty. Stanowiska te traktowane są co prawda jako wspólny potencjał przewozowy, ale rozdziela się je na poszczególnych partnerów, którzy mogą konkurować miedzy sobą ceną i jakością świadczonych usług. Jak z tego wynika, na jednym statku załadowcy mogą zawierać umowy z różnymi gestorami slotów ${ }^{23}$.

Oczywiście opisane w niniejszym podrozdziale porozumienia integracyjne nie są jedynymi możliwymi formami współpracy przewoźników morskich. W żegludze kontenerowej można się bowiem spotkać z różnego rodzaju porozumieniami polegającymi na wspólnej eksploatacji terminali portowych, statków, szlaków czy też zarówno statków, jak i szlaków dowozowych. Część operatorów decyduje się również na prowadzenie wspólnej polityki taryfowej lub sprzedaż usług za pośrednictwem jednego agenta bądź wspólnie utworzonej spółki. Możliwymi formami kooperacji są także czasowe zarządzanie statkiem innego armatora, podział statków (koszty eksploatacji rozlicza się według wysokości udziałów armatorów na każdej z jednostek pływających należących do porozumienia) oraz podział tonażu (przewoźnicy ustalają pojemność i nośność jaką będą dysponować na poszczególnych statkach serwisu ${ }^{24}$.

\section{Polityka integracyjna operatorów kontenerowych w kontekście przepisów Unii Europejskiej}

Opisane w poprzednim podrozdziale formy współpracy integracyjnej armatorów nie mogą funkcjonować w oderwaniu od obowiązujących na świecie norm i przepisów prawnych. Przykładowo, znowelizowanie międzynarodowego ustawodawstwa antymonopolowego osłabiło rolę wszelkiego rodzaju porozumień cenowych pomiędzy przewoźnikami morskimi. Podobnie konsekwentne wdrażanie przez Unię Europejską koncepcji rozwoju zrównoważonego transportu wpływa na stopniowe osłabianie roli porozumień konferencyjnych w żegludze liniowej.

Uregulowania ogólnoświatowe dotyczące międzynarodowej żeglugi morskiej zawarte są w konwencjach $\mathrm{ONZ}^{25}$ oraz konwencjach i standardach wypracowanych pod auspicjami Międzynarodowej Organizacji Morskiej (IMO). Regulują one przede wszystkim kwestie dotyczące bezpieczeństwa życia na morzu, ochrony środowiska morskiego przed zanieczyszczeniem, wolności żeglugi i obowiązków państw w zakresie stanu technicznego statków pływających pod ich banderą. W związku z tym, w odniesieniu do transportu morskiego, Unia Europejska

${ }^{23}$ Deloitte, dz. cyt., s. 17.

${ }^{24}$ J. Neider, D. Marciniak-Neider, $d z$. cyt., s. 89.

${ }^{25}$ Por. Konwencja Narodów Zjednoczonych o Prawie Morza z dnia 10 grudnia 1982 r.; Konwencja Narodów Zjednoczonych w sprawie kodeksu postępowania dla Konferencji Linii Żeglugowych $z$ dnia 6 października $1983 r$. 
zajmuje się tylko wybranymi zagadnieniami, szczególnie tymi, które dotyczą aspektów ekonomicznych ${ }^{26}$.

Jeśli chodzi o transport morski, Komisja za najważniejszą uznała zasadę swobody świadczenia usług (rozporząadzenie Rady nr 4055/86). Podstawowym dokumentem regulującym stosowanie traktatowych zasad konkurencji w żegludze liniowej ${ }^{27}$ stało się natomiast rozporządzenie Rady $\mathrm{nr} 4056 / 86$. W jego preambule powołano się m.in. na art. 3 Traktatu ustanawiającego Wspólnotę Europejską (TWE) przewidujący zniesienie przeszkód w swobodnym przepływie usług między państwami członkowskimi oraz art. 51 przewidujący swobodę świadczenia usług transportowych. Wspomniane rozporządzenie zwalniało konferencje morskie z zakresu określonego $\mathrm{W}$ art. 81 ust. $1 \mathrm{TWE}^{28}$. W efekcie konferencje żeglugowe uzyskały pozwolenie na ustalanie cen oraz regulowanie zdolności przewozowych ${ }^{29}$. Komisja przyjęła także stosowne rozporządzenie o wyłączeniu z zasad konkurencji porozumień linii żeglugowych tworzących konsorcja. Uznano, że konsorcja są porozumieniami o współpracy pomiędzy przedsiębiorstwami żeglugi liniowej, które nie wiążą się z ustalaniem cen, a przyczyniają się do racjonalizacji przewozów dzięki wykorzystaniu wspólnych środków technicznych, organizacyjnych bądź handlowych ${ }^{30}$.

Warto w tym miejscu nadmienić, że już w 1986 r. wspomniane rozporządzenia były przez niektórych krytykowane, a wyłączenie konsorcjów i konferencji liniowych spod zakazu praktyk monopolistycznych uznawano za niesłuszne. Jednak

${ }^{26}$ K. Dąbrowski, Uregulowania Wspólnoty Europejskiej w transporcie morskim a polska polityka żeglugowa (aspekty ekonomiczne), „Studia Europejskie” 1998, nr 1, s. 108.

${ }^{27} \mathrm{~W}$ dokumencie nie uregulowano usług żeglugi trampowej, w ramach której stawki frachtowe mogły być ustalane zgodnie $\mathrm{z}$ regułami wolnego rynku.

${ }^{28}$ „Niezgodne ze wspólnym rynkiem i zakazane sq wszelkie porozumienia między przedsiębiorstwami, wszelkie decyzje związków przedsiębiorstw i wszelkie praktyki uzgodnione, które moga wptywać na handel między Państwami Członkowskimi i których celem lub skutkiem jest zapobieżenie, ograniczenie lub zakłócenie konkurencji wewnątrz wspólnego rynku, a w szczególności te, które polegaja na: a) ustalaniu w sposób bezpośredni lub pośredni cen zakupu lub sprzedaży albo innych warunków transakcji, b) ograniczaniu lub kontrolowaniu produkcji, rynków, rozwoju technicznego lub inwestycji, c) podziale rynków lub źródet zaopatrzenia, d) stosowaniu wobec partnerów handlowych nierównych warunków do świadczeń równoważnych i stwarzaniu im przez to niekorzystnych warunków konkurencji, e) uzależnianiu zawarcia kontraktów od przyjęcia przez partnerów zobowiąań dodatkowych, które ze względu na swój charakter lub zwyczaje handlowe nie maja zwiazku z przedmiotem tych kontraktów". Por. Art. 81 ust. 1 TWE (Obecnie art. 101 ust. 1 Traktatu o funkcjonowaniu Unii Europejskiej (TFUE)).

${ }^{29}$ Należy pamiętać, że państwa Europejskiej Wspólnoty Gospodarczej (EWG) musiały wcześniej zająć wspólne stanowisko wobec Konwencji Narodów Zjednoczonych z 1974 r. o Kodeksie Postępowania Konferencji Żeglugi Liniowej. Ostatecznie w 1979 r. przyjęty został tzw. Pakiet Brukselski, który określił przepisy, zgodnie z którymi kraje członkowskie mogły przystąpić do wspomnianej Konwencji pod warunkiem wyłączenia niektórych jej postanowień w relacjach między sobą oraz z OECD. Zob. J. Kujawa, Europejska polityka żeglugowa, „Contemporary Economy”, Vol. 5, Issue 1/2014, s. 41.

${ }^{30}$ K. Dąbrowski, dz. cyt., s. 110; 114; 116; 118. 
praktycznie aż do przełomu wieków XX i XXI Rada podtrzymywała swoje stanowisko uznając, iż obniżki kosztów linii konferencyjnych nie wpływają na ceny przewozu, a zatem nie przynoszą korzyści załadowcom.

$\mathrm{Z}$ czasem Komisja uznała, że konferencje w nowych uwarunkowaniach gospodarczych zwiększają ryzyko antykonkurencyjnych praktyk rynkowych. W październiku 2004 r. opublikowana została zatem tzw. „Biała Księga” zawierająca sugerowane kierunki zmian reguł konkurencji w transporcie morskim oraz propozycję objęcia nadzorem antymonopolowym również żeglugi trampowej i kabotażu morskiego ${ }^{31}$. Tym samym Komisja wyraziła swoje przekonanie o potrzebie nie tylko ograniczenia immunitetu konferencji żeglugowych od zakazów sformułowanych w art. 81 traktatu TWE, ale nawet zabronienia ich funkcjonowania na rynkach frachtowych Unii Europejskiej ${ }^{32}$.

Jednak decyzja o uchyleniu rozporządzenia $\mathrm{nr}$ 4056/86 weszła w życie dopiero po dwóch latach (rozporządzenie Rady nr 1419/2006). Zgodnie z postanowieniami zawartymi w tym dokumencie immunitet konferencyjny utrzymany był przez kolejne dwa lata, do 18 października 2008 r. Po tej dacie jedynymi dopuszczalnymi formami współpracy na szlakach do i z Unii Europejskiej stały się porozumienia o charakterze operacyjnym, w tym konsorcja i alianse kontenerowe, w których ceny nie są odgórnie ustalane. Co istotne, zgodnie z nowymi przepisami również żegluga trampowa i kabotaż poddane zostały antymonopolowemu nadzorowi ze strony Dyrekcji Generalnej ds. Konkurencji. W rozporządzeniu z 2006 r. znowelizowano tym samym rozporządzenie Rady $\mathrm{nr}$ 1/2003 dotyczące ogólnych reguł stosowania art. 81 i 82 dawnego Traktatu Rzymskiego ${ }^{33}$.

W kolejnych latach Unia Europejska wprowadzała w transporcie morskim coraz bardziej restrykcyjne reguły konkurencji. Już we wrześniu 2009 r. Komisja Europejska podjęła decyzję ograniczającą swobodę funkcjonowania konsorcjów kontenerowych. Ponadto według obowiązującego od kwietnia 2010 r. rozporządzenia Komisji nr 906/2009 przywilej automatycznego, grupowego zwolnienia od zakazu porozumień rynkowych ${ }^{34}$ został ograniczony do konsorcjów, których

${ }^{31}$ Art. 32 rozporządzenia Rady nr 1/2003 w sprawie wprowadzenia w życie reguł konkurencji ustanowionych w art. 81 i 82 TWE wyłączał żeglugę trampową i kabotaż morski spod uregulowań zawartych w tym rozporządzeniu. Trzeba jednocześnie pamiętać, iż zgodnie z rozporządzeniem Rady nr 3577/92 od 01.01.1993 r. obowiązywała zasada liberalizacji kabotażu dla wspólnotowych armatorów eksploatujących statki zarejestrowane w jednym z państw członkowskich.

${ }^{32}$ J. Kujawa, Biała Księga o regułach konkurencji w żegludze, „Namiary na Morze i Handel” 2005, nr 1, s. 15-16.

${ }^{33}$ Tenże, Konferencje żeglugowe traca immunitet (na razie w Europie), „Namiary na Morze i Handel” 2006, nr 20, s. 14-15; J. Neider, Stosunek Unii Europejskiej do konferencji żeglugowych, „Zeszyty Naukowe UE w Poznaniu" 2009, nr 126, s. 374-382.

${ }^{34}$ „Jednakże postanowienia ustẹpu 1 moga zostać uznane za nie majace zastosowania do: każdego porozumienia lub kategorii porozumień między przedsiębiorstwami; każdej decyzji lub kategorii decyzji związków przedsiębiorstw; każdej praktyki uzgodnionej lub kategorii praktyk uzgodnionych, które przyczyniaja się do polepszenia produkcji lub dystrybucji produktów bądź do popierania postępu technicz- 
udział (także liczony w nowy sposób) w rynku jest nie większy od 30\%. Aby uniknąć zbyt daleko idącej reorganizacji europejskiego rynku przewozów kontenerowych, Komisja zagwarantowała jednak, iż niewielkie przekroczenie limitu udziału rynkowego, trwające nie dłużej niż dwa lata, nie będzie skutkowało odebraniem immunitetu od przepisów antymonopolowych. Jednocześnie w omawianym rozporządzeniu zapisano, że przekroczenie większe niż o 1/10 musi być usunięte w ciągu pół roku lub roku w przypadku, gdy jest ono spowodowane wycofaniem się z rynku operatora niebędącego członkiem konsorcjum ${ }^{35}$.

Ponadto w 2009 r. Komisja przedłożyła komunikat dotyczący strategicznych celów i zaleceń w zakresie polityki transportu morskiego Unii Europejskiej do 2018 r. Przedstawiła w nim główne możliwości strategiczne dla unijnego systemu transportu morskiego, podkreślając szczególną rolę takich zagadnień jak:

- żegluga morska UE w kontekście zglobalizowanych rynków oraz większej konkurencji;

- zasoby ludzkie, praktyka morska i morskie know-how;

- bezodpadowy i bezemisyjny transport morski;

- poprawa bezpieczeństwa transportu morskiego oraz przeciwdziałanie terroryzmowi i piractwu;

- wykorzystanie w pełni potencjału żeglugi morskiej bliskiego zasięgu;

- badania naukowe i innowacje ${ }^{36}$.

Na chwilę obecną wydaje się, że znaczenie konferencji frachtowych znacząco zmalało. Jest to wynikiem nie tylko dynamicznie postępującej konteneryzacji przewozów morskich, ale i nowej organizacji żeglugi liniowej. Delegalizacja konferencji frachtowych spowodowała bowiem silne zaostrzenie konkurencji między amatorami. Przyspieszyło to procesy koncentracji, przez co większość przewozów kontenerowych jest dziś realizowana przez szesnastu operatorów należących do czterech aliansów globalnych: $2 M$, Ocean Three, G-6 i $C K Y H E^{37}$.

nego lub gospodarczego, przy zastrzė̇eniu dla użytkowników stusznej części zysku, który z tego wynika, oraz bez: a) nakładania na zainteresowane przedsiębiorstwa ograniczeń, które nie sa niezbędne do osiagnięcia tych celów, b) dawania przedsiębiorstwom możliwości eliminowania konkurencji $w$ stosunku do znacznej części danych produktów". Por. Art. 81 ust. 3 TWE (Obecnie art. 101 ust. 3 TFUE).

${ }^{35}$ J. Kujawa, Nowe reguty dla konsorcjów kontenerowych, „Namiary na Morze i Handel” 2010, nr 4, s. 23-24.

${ }^{36}$ Por. Komunikat Komisji do Parlamentu Europejskiego, Rady, Europejskiego Komitetu Ekonomiczno-Społecznego i Komitetu Regionów: „Strategiczne cele i zalecenia w zakresie polityki transportu morskiego UE do 2018 r.”, Bruksela 2009.

${ }^{37}$ Alians $2 M$ to współpraca Maersk Line oraz Mediterranean Shipping Company, do porozumienia Ocean Three należą CMA CGM, China Shipping oraz United Arab Shipping Co. Z kolei alians G-6 to stowarzyszenie, które wspólnie z Hapag-Lloyd tworzą armatorzy APL, Hyundai Merchant Marine, Mitsui O.S.L. Line, Nippon Yusen Kaisha i Orient Overseas Container Line. Do grupy CKYHE należą Cosco, "K” Line, Yang Ming, Hanjin oraz od niedawna Evergeen. 


\section{Zakończenie}

Polityka Unii Europejskiej w odniesieniu do transportu morskiego łączy rozwiązania respektujące podstawowe zasady liberalizmu z umiarkowaną protekcją własnej żeglugi. $Z$ jednej strony obecne działania Unii w zakresie kształtowania warunków konkurencji na rynkach żeglugowych chronią eksporterów i importerów krajów członkowskich przed efektami globalnej konkurencji, z drugiej jednak osłabienie pozycji konferencji frachtowych i konsorcjów zaostrza rywalizację pomiędzy amatorami, co grozi usunięciem części przewoźników z rynku i doprowadzić może w przyszłości do praktyk monopolistycznych ze strony operatorów działających w ramach tworzących się w ostatnim czasie aliansów strategicznych.

Aleksandra Bartosiewicz

\section{INTEGRATION AGREEMENTS IN CONTAINER SHIPPING. THE ORIGIN, DEVELOPMENT AND CURRENT STATE IN THE CONTEXT OF THE EURO- PEAN UNION LAW}

Common maritime transport policy in Europe was developed only in the mid 70-ties of the $20^{\text {th }}$ century. It was mainly due to the provisions of the Treaty of Rome according to which any decisions on common maritime transport had been postponed indefinitely. The Council Regulation No 141/62 was in force until the end of 1986. It excluded the maritime transport from the regulations concerning competition issues. The following sections of the article present both basic types of integration agreements between shipowners (especially those operating in container shipping) that were formed at the time described and the European Union changing attitude towards freedom of service provision in the maritime transport. 